\title{
Charles Chesnutt and the case for hybrid editing
}

\author{
Stephanie P. Browner ${ }^{1} \cdot$ Kenneth M. Price ${ }^{2}$
}

Published online: 3 May 2019

(C) The Author(s) 2019

\begin{abstract}
In the context of a specific hybrid project - a digital archive and a print edition of the complete works of American writer Charles W. Chesnutt (1858-1932)-we consider three issues: (1) the value of print editions, notwithstanding the flexibility, capaciousness, and accessibility of digital editions; (2) the distinct affordances of digital editing in general and in this case; and (3) the challenges of a hybrid approach, and the possiblility of supplementing the now standard digital approach to rendering paper manuscripts (high quality scans and TEI-compliant transcriptions) with approaches borrowed from print and print aesthetics.
\end{abstract}

Keywords Editing · Digital · Print · Archive · American · African American · Fiction

In this essay we consider three questions about digital and print editing in the context of a specific hybrid project - a digital archive and a print edition of the complete works of American writer Charles W. Chesnutt (1858-1932). First, why should a print edition be undertaken given the flexibility, capaciousness, and (typically) greater accessibility of a digital edition? Second, what does a digital archive offer that a print edition cannot, and what are the distinct affordances of digital editing in general and in this case? Finally, what issues emerge with a hybrid approach, and what experiments are possible, specifically in supplementing the now standard digital approach to rendering paper manuscripts (high quality scans and TEI-compliant transcriptions) with approaches borrowed from print and print aesthetics?

Stephanie P. Browner

browners@newschool.edu

Kenneth M. Price

kprice2@unl.edu

1 Literary Studies, The New School, New York, NY, USA

2 Department of English, University of Nebraska-Lincoln, Lincoln, NE, USA 


\section{I. Why print?}

Four years ago, Oxford University Press approached us about a print scholarly edition of the works of Chesnutt. No doubt Oxford recognized that Chesnutt's fiction is at the center of groundbreaking scholarship on race and has been for decades. Chesnutt began writing in earnest in the last years of the nineteenth century, a racial nadir for the nation as Reconstruction failed and white supremacy took new virulent forms. The topics he addressed remain critically important today-race, identity, violence, class, property, and the largely unrecognized familial, social, and economic relations that zigzag across America's color line. Oxford also recognized the need not just for editions of selected works but for a comprehensive, multi-volume scholarly edition capable of undergirding critical studies for decades. Heretofore, scholars have typically worked with only a fraction of Chesnutt's oeuvre: a few works are reprinted often; others come in and out of print; and some of Chesnutt's fiction has not yet reached print.

The question we faced was why undertake a scholarly print series if editing in a digital environment offers real advantages, despite significant challenges. Moreover, a digital Chesnutt project already exists - The Charles Chesnutt Digital Archive. It is a twenty-year-old HTML site in need of updating, and yet it is used often by students, teachers, and scholars. Indeed, Oxford approached us because we serve as editors of The Charles Chesnutt Digital Archive.

With the rise of digital editing, some may wonder if print editions still have a major role to play in scholarly editing. In our field of American literature, the answer is yes. Currently, there are multi-volume print editions in process for Henry James, Mark Twain, Willa Cather, Charles Brockden Brown, and Frederick Douglass with Cambridge University Press, University of California Press, University of Nebraska Press, Bucknell University Press, and Yale University Press, respectively. Planning is also underway at Oxford University Press for editions devoted to Edith Wharton and Harriet Beecher Stowe.

Broadly speaking, African American writers have not received the extensive editorial attention granted their white peers, with the exception of historical figures such as Booker T. Washington and Frederick Douglass. Thus, the readiness of Oxford University Press to publish ten volumes of Chesnutt's work in a richly annotated scholarly edition is a notable development in the history of editing and of canon formation. Decisions about what we preserve and edit are always important, and we believe that scholarly engagement with all the works is not only important, but urgent, and that print - not just paperback editions for the classroom, and not only a digital archive, but a multivolume scholarly print edition - has a role to play in meeting this need.

Chesnutt was born in the North to parents who fled the South before the war and returned to North Carolina when he was eight. During Reconstruction, his father was a county justice of the peace in Fayetteville, North Carolina, and he joined with other African American men to buy land with the assistance of the Freedmen's Bureau and build a public school, which Chesnutt attended. By the time he was sixteen and Reconstruction was faltering, Chesnutt was teaching in schools in North Carolina and South Carolina. He was self-taught in the Classics, and at eighteen he returned to Fayetteville to serve as assistant principal of the school he had attended as a boy. By act of the North Carolina General Assembly, it was now the State Colored Normal School, the first and only institution in the state where African Americans could secure teacher 
training. In 1883, he left North Carolina for New York, where he worked briefly as a Wall Street reporter for Dow Jones \& Company. Later that year, at the age of twentyfive and as violence against African Americans continued to rise, he moved his wife and three children to Cleveland, where he passed the Ohio bar with the highest score in his cohort and set up his own court reporting stenography business.

Chesnutt's writings are remarkably varied in style and voice. As archival materials and correspondence reveal, he worked assiduously at his craft, revising and reshaping his work again and again. He was prolific and wrote in a wide variety of genres. He probed deeply and imaginatively, with both an ethical sense and a capacity for play, some of the most complex issues in American society. At twenty-two, he declared his calling in his journal-'I think I must write a book' (Chesnutt 1993, p. 139). He began publishing in earnest in 1885, and within five years he had placed thirty-nine short stories, including three in The Atlantic Monthly, the first African American author to do so. In 1899, Small Maynard commissioned Chesnutt to write a biography of Frederick Douglass, the first after Douglass's death, for their Biography of Eminent Americans series. Houghton Mifflin, another premier publisher, brought out two of his short story collections that same year and his first and second novels in 1900 and 1901. Chesnutt published a third novel a few years later, and he continued to place stories and essays in magazines. There were disappointments along the way, too. For example, he was distraught over the reception given to The Marrow of Tradition, his incisive account of the overthrow of a duly elected mixed-race government in Wilmington, North Carolina by violent white supremacists. By the time of his death in 1932, he had written nine novels (though no more had been published), eighty-five short stories (all but a few published), and more than seventy essays and speeches, but nothing was in print. We expect that more work on the lesser known writings of Chesnutt will shed light on the combination of forces - personal, political, financial - that left so many novels in manuscript form.

A great age of scholarly editions for American writers began in the 1960s. As Americans went to college in large numbers after World War II, college literature classes proliferated. At the same time, New Criticism's close reading method took hold, and a US literary canon was established. A complete works for Herman Melville, who like Chesnutt was largely out of print, was started by Northwestern University Press, Newberry Library, and the Modern Language Association (MLA) in 1961, with funding from the US Department of Education. That same year, another group of editors secured funding from the Department of Education for a Mark Twain edition with the University of California Press and the MLA. The Ohio State University Press edition of Nathaniel Hawthorne released its first volume in 1962, and the Indiana University Press edition of William Dean Howells was launched in 1968.

The history of editions for non-white writers and many women writers, often added later to the canon and in response to political movements, is notably different. The 1960s Civil Rights Movement increased popular interest in black writers and spurred the recovery of texts out of print. Thus, although Chesnutt was not yet taught in college classrooms, his writings began to be reprinted in the 1960s, but with minimal institutional investment. In 1968, a small press in New Jersey and the University of Michigan Press issued reprints of four of Chesnutt's five books of fiction-both 1899 short story collections and his 1901 and 1905 novels, The House Behind the Cedars and The Colonel's Dream, respectively. These were photographic reprints of the original 
editions: no new typesetting, no notes, and no introductions. The first scholarly editorial effort came five years later, when Sylvia Lyons Render, a Library of Congress historian, gathered Chesnutt's magazine fiction, those stories not included in the 1899 collections. Render's The Short Fiction of Charles Chesnutt (Render 1974) was a landmark contribution to African American studies. It offered fifty-five short stories, organized by genre (tale, short story, sketch). Her introductory essay offered interpretive comments, orienting students and scholars to a body of work just starting to gain attention. But Render did not produce a scholarly edition. She found stories that had never been republished, but she provides neither publication dates nor bibliographic information about where the stories first appeared. She includes unpublished stories, but is silent about her transcription policy and archival research methods. Oddly, the collection omits without explanation both published and unpublished stories. In fact, Render is completely mute on editorial approach and selection criteria, and the stories are not annotated. Though missing these elements of a scholarly edition, and now out of print and increasingly difficult to purchase, Render's collection remains the sole source for many of Chesnutt's short stories.

The next Chesnutt editions were mass market paperbacks. A leading Chesnutt scholar, William Andrews, published a collection of Chesnutt's short works with Signet in 1992, and Donald Gibson, a scholar who dedicated his life to bringing African American authors into print and into the college curriculum, published an edition of Chesnutt's first novel, The House Behind the Cedars, with Penguin in 1993. Later in the decade, scholars turned to university presses to bring out some of Chesnutt's unpublished works - specifically novels with race as a central theme. Like the mass market paperbacks, these offer introductions for the general reader, but no annotations or textual apparatus regarding variants and manuscript history. Perhaps representative of textual scholarship on Chesnutt at this time is Charles Hackenberry's (1997) edition of Mandy Oxendine. Hackenberry notes in the introduction that for his dissertation he rendered 'all features of the typescript - cancellations, interlineation, variant readings, original pagination, and amendments' of the text (p. xxvii). By contrast, his edition of the novel, published by the University of Illinois in 1997 but now out of print, offers no annotations or examples of Chesnutt's revisions.

In the next decade, as Chesnutt's significance was increasingly recognized, more robust teaching editions appeared. Houghton Mifflin added Chesnutt to their New Riverside Editions series edited by Paul Lauter. The volume, edited by SallyAnn Ferguson, included journal entries, essays, short stories, and recent literary criticism. The well-established Norton Critical Edition series added Chesnutt with Werner Sollors' edition of the novel The Marrow of Tradition. Aimed at college students, these editions typically include criticism from diverse traditions. Sollors supplemented the text of Chesnutt's 1901 novel about the 1898 Wilmington, North Carolina riots with selected letters and essays, historically relevant materials, and recent literary criticism. The Marrow of Tradition also appeared in a Bedford Cultural Edition, a competitor to the Norton Critical Editions. Richard Brodhead, an early contributor to the Chesnutt revival, published a volume of selections from Chesnutt's youthful journals and edited The Conjure Woman, adding the conjure tales that Chesnutt did not include in the original 1899 collection. Later, this same expanded collection of conjure stories appeared in a Norton Critical Edition. Robert Stepto, the editor, included the kind of 
secondary materials that are typical in that series, along with maps depicting the town and region of Patesville, the fictional setting of the conjure tales. Stepto also challenged the interpretation and editorial decisions in Brodhead's earlier edition, making this the first time Chesnutt editing moved into a prominent scholarly discussion. Meanwhile, Andrews updated his Penguin edition, and other scholars created additional thematic teaching collections of Chesnutt's short works. Two of his unpublished white-life novels were made available for general audiences - these publications featured introductions but lacked annotations and editorial apparatus.

Chesnutt had fully arrived, one might conclude, with the publication of a Modern Library edition of his first novel, The House Behind the Cedars, and a few years later with the appearance of a Library of America volume. The latter, edited by Werner Sollors, offers thoughtful annotations, a thorough 'Note on the Texts', and a substantive bulleted chronology of Chesnutt's life. The edition brings together in a single volume those works that had up to that moment most interested teachers and scholars: both 1899 short story collections, two novels (The House Behind the Cedars and The Marrow of Tradition), additional stories, including four which had not appeared since Render's 1974 edition, and seven essays. While nicely wide-ranging and handsomely printed, the Library of America edition still offered only a fraction of Chesnutt's oeuvre. By this time, Chesnutt scholars had access to the invaluable literary biography by William Andrews and three scholarly editions, though not of his fiction. Led by Joseph R. McElrath, Jr. and Robert C. Leitz, III, these editions were: two volumes of selected letters, published with Princeton University Press, and The Complete Essays and Speeches with Stanford University Press.

This history testifies to decades of growing interest in Chesnutt, interest that is lively, vibrant, and always finding new directions. It also reveals that although Chesnutt's works have now been edited for fifty years, little progress has been made in bringing Chesnutt fully or systematically into view. Currently, less than half of his works are in print; very little is annotated; almost none has benefited from rigorous textual editing; and attention to Chesnutt's writing and revision process as evidenced in drafts and revised manuscripts and typescripts is essentially non-existent.

Our decision to embark upon a print scholarly edition is, in many ways, a response to this history. Getting everything published, in one place, with full scholarly treatment, with a major press, will bring Chesnutt editing up to date and contribute to his rising stature. As the history outlined above indicates, editing has been selective, and what is available has been shaped by the scholarly interests that first dominated Chesnutt studies. These interests include Chesnutt's relationship with the white publishing world, his use of conjure in his early fiction, and his interest in the color line. Scholarship is rapidly raising new questions, and scholars are beginning to work with a greater range of Chesnutt's fiction, though without the benefit of scholarly editions of these less familiar works. There is little doubt that a complete scholarly edition will change the landscape of Chesnutt studies and American literary studies. For example, the fourteen frequently reprinted conjure stories, which are set in the fictional town of Patesville, will appear for the first time alongside ten other Patesville stories, which were written at the same time but which do not feature conjure and which work very differently with issues such as race, property ownership, and slavery's legacy. Completeness, along with the kinds of annotations we expect in a scholarly edition-information about literary, historical, social, and cultural contexts as well as about drafts, revisions, and 
publication history - will also allow scholars to construct different career arcs for Chesnutt. There is no doubt that Chesnutt wanted to be published, that his relationships with white writers-William Dean Howells, George Washington Cable, and Walter Hines Page - were important and decisive in his literary career, and that race dynamics shaped these relationships, much as they also shaped US publishing and literary history. But extensive scholarship on US periodical fiction has transformed our understanding of the literary marketplace of the second half of the nineteenth century. Scholars have unpacked the construction of belles-lettres in these decades, and we have a fuller understanding of the explosion in serial, magazine, and syndicate publishing and the rise of African American publishing. The envisioned ten-volume complete works of Chesnutt will serve as an invaluable source for future endeavors in understanding US publishing history, and in innumerable other areas of scholarly inquiry across literary, cultural, and historical studies.

\section{Part II. Editions and archives}

There is no reason to think a digital scholarly edition could not do this just as well. We know the advantages of editing in a digital environment. But we also know the challenges and especially the difficulty of securing years of external funding and the long-term commitment of institutional support necessary to develop, complete, and maintain a high-quality digital scholarly project. There is also lingering uncertainty about preservation of digital content. Can it be maintained, refreshed, and migrated as necessary, not just over months and years but decades and centuries? Who will do this, and who will pay for it? A partnership with Oxford University Press releases the team of Chesnutt editors from these worries and insecurities. But print publication generates its own concerns. Why should a project be limited just to what is feasible to present in print? Why should access to high-level scholarship be limited to those with sufficient wealth to buy expensive volumes or with access to the library of a research university? Why should an edition be made for sale when it is possible to imagine it being constructed as an open-access resource, which allows repurposing in ways we cannot foresee? In Chesnutt's case, a digital edition of his writings might be combined productively for broader computational analysis with the works of writers from the Midwest, or writers of the nineteenth century, or other African American writers. In short, one should not launch a major editing project in either medium without an honest reckoning with what is gained and what is lost. Chesnutt editing, we believe, can and should go forward in both print and digital, simultaneously. This, too, of course, brings challenges, including how to maximize complementarity and avoid duplication and how to navigate the very different terrains of proprietary and non-proprietary endeavors.

Digital projects for major American writers now abound, and scholars working on print editions are often involved. Many of these projects intervene in specific editorial debates or serve as an archive of a set of primary materials. Others are more ambitious, seeking to make the kind of contribution we expect from a complete works print series and, at the same time, to be an even more encompassing digital archive or a digital thematic research collection, or 'knowledge site', as it has been variously called (Palmer 2004, 351; Shillingsburg 2006, 100). The Mark Twain Project Online 
(2018), for example, proposes to 'produce a digital critical edition, fully annotated, of everything Mark Twain wrote' and 'to offer unfettered, intuitive access to reliable texts, accurate and exhaustive notes, and the most recently discovered letters and documents'. It is the child of the print editions that began appearing in the 1960s; three editors who participated in the launch of the print edition decades ago are still with the project; and support continues to come from the University of California Press. Neither the US Department of Education nor the MLA are still involved, but the project regularly gains grant support, and the Bancroft Library at the University of California, Berkeley hosts the site as a permanent partner. The Twain project also benefits from generous private donors. In contrast, The Walt Whitman Archive, which started about a decade after the New York University Press 22-volume series The Collected Writings of Walt Whitman (1961-1984) had published its last volume, is not a descendant of a print effort, nor has it opted for a print correlate. Committed to making 'Whitman's vast work freely and conveniently accessible to scholars, students, and general readers', the Whitman Archive (2018) draws on 'the resources of libraries and collections from around the world' and has become 'the most comprehensive record of works by and about Whitman'. It, too, has steadily secured grant funding and has built a permanent endowment to support ongoing editorial work and sustain the archive into the indefinite future. Notably, both digital projects began after scholars dedicated decades to print editions, and Whitman and Twain are among America's most iconic writers.

So, how best to edit Chesnutt in print and digital, simultaneously? The print series should, through sophisticated apparatuses, document and make accessible the textual histories of Chesnutt's works, while recognizing that print editing tends to drive toward a single authoritative edition, in part as a response to the constraints of physical books, volume length, and cost. The digital effort should maximize the capaciousness, openendedness, and inclusiveness possible in a digital environment. In fact, the very notion of 'complete' or 'comprehensive' has a different horizon of possibility in a digital environment. In short, print edition and digital archive are useful shorthand terms, albeit with caveats, for the distinctive goals of this hybrid effort to edit Chesnutt in both media.

To probe more precisely the different affordances of editing Chesnutt in print and digital, it is useful to consider The House Behind the Cedars (Chesnutt 1900). This was Chesnutt's first published novel, and it was important to him personally, critical to his professional life, and of great interest to his contemporaries. Within a year of its publication, House had been reviewed in more than forty newspapers and magazines, including in The Nation, The Saturday Review, The New York Times Book Review, The Living Age, Boston Evening Transcript, and The Chicago Daily Tribune. It also ran as a serial in Modern Culture, concurrent with the book publication, and then twenty years later in The Chicago Defender, one of the nation's leading African American newspapers. Oscar Micheaux twice made it into a film: a 1927 silent film, which played in theaters across the country and was reviewed in the black press, and then as a talkie in 1932, starring Lorenzo Tucker and Laura Bowman. The novel is now the subject of incisive critical commentary; it is taught in classes across the US and many mass market editions are readily available.

It is also the work for which we have the most extensive manuscript record. It began as a short story, 'Rena Walden,' drafted in the late 1880 s. For the next twelve years, Chesnutt revised extensively, shared drafts with others, and 
submitted it for publication multiple times. Chesnutt's commitment to the story is notable. As early as 1890 , when he gathered stories for a proposed collection, in a letter to the publisher he suggested naming "the volume "Rena Walden and Other Stories", or simply "Rena Walden"'. He was open to changes, barring one: "I would be quite willing to reduce the number of the stories and leave out any that might be suggested, always excepting the longer one, 'Rena Walden'. Late in life, Chesnutt said the novel was 'in many ways my favorite child' (16 June 1930).

The manuscript record for 'Rena' is more than 500 leaves. Most are typescript, and two-thirds have pencil and pen revisions in Chesnutt's hand. There are also some thirty handwritten leaves, often on scraps of paper. Helen Chesnutt gave her father's papers to Fisk University in 1952, and she or perhaps a Fisk archivist organized the materials into five folders, numbered, presumably, chronologically. But, as it turns out, the versions are not numbered in a sequence that reflects the evolving composition. The version labeled \#4, for example, is the earliest, and the version labeled \#2 is the latest, the one closest to the 1900 published version. There is also uncertainty about each version: are the right pages gathered together in each folder? On some leaves, typed page numbers are revised, in Chesnutt's hand, suggesting a plan to incorporate them into a later version. Can we determine whether these pages are accurately filed? In one folder, for example, there are four groupings of between two and forty leaves. Do these four groups all come from the same draft? Are the seven handwritten pages in this folder, which are clearly a beginning, the beginning of the version represented in the typewritten pages?

Print editions struggle to do justice to works with complex manuscript histories. Given the richness of the manuscript history in this instance and the series' commitment to highlighting Chesnutt's writing process, the print volume for The House Behind the Cedars will include a transcription of the earliest version. In addition, the introduction will describe the manuscript history and the various intermediate versions, as well as the publication history; and the editorial apparatus will aim to convey the nature and extent of the changes Chesnutt made over the five versions. But even the task of coming to a clear reading copy of the earliest version is fraught. How do we understand the handwritten changes on the page? Were they improvements to this version as he prepared it for publication, or were they made months or years later as he shaped a new version?

Across the five versions such questions multiply in number and complexity. Any print edition must, in the end, come to conclusions about the archival materials, including such basic questions as which leaves are related and how. Introductions and annotations can provide the evidence behind the decision, but the edition inevitably offers a particular theory about the archival materials. The tasks of organizing and encoding documents for a digital archive also require answers to such questions. But without print's cost (or at least with a radically different set of economic considerations) and without volume-length constraints, a digital archive should ideally allow access to the full manuscript record, thus facilitating alternative understandings of the evidence.

The work of Emily Dickinson editors is instructive here. Over the last forty years, three of the most accomplished Dickinson scholars, Thomas Johnson, Ralph Franklin, and Cristanne Miller, have created print editions that came to notably different conclusions about how best to present her work, about the composition dates, and even, in 
several cases, about whether certain stanzas make up a single poem or separate poems. Ultimately, each editor made an argument based on extensive work in the repositories and careful examination of the physical evidence. Working in a digital archive will never be the same as working with the physical materials. But by offering high quality images of materials from collections across the country or world, as well as accurate transcriptions, all carefully encoded, digital archives allow more scholars, students, and teachers, as well as readers with funding and readers without, to join the discussion and to develop alternative theories and hypotheses about a work's history and a writer's process of composition. Widespread access to a digital archive of the 'Rena' manuscripts will allow scholars to debate the chronological order of the versions and even which leaves make up a single version.

Increased access to 'Rena' manuscripts will also, almost surely, expand the interpretive frames we use to think about a work that has become a core text in race studies and iconic in the history of racial passing. What will surprise many is that the first version is not about passing at all. The novel's first incarnation was a short story with a focus on color snobbery and the difficulties faced by a mixed-race woman with 'bluish gray' eyes and a face that was 'almost transparently fair.' This young woman, 'Rena', makes an unhappy marriage at her mother's prodding to a poor-but-posing-as-rich light-skinned man. This early version has no white characters, other than the frame narrator. This was the story sent to the Atlantic and Century. The next version further details the unhappy marriage and the backstory of Rena's mother. It also expands the presence of the frame narrator, a structure Chesnutt later jettisoned. The third version adds a white character, and Rena passes, but when the white lover discovers her lineage, he rejects her, and she then makes the unhappy marriage to the light-skinned man. In the published version, she never marries. Instead, after the white lover's rejection, she becomes a teacher in a rural school for young black children, work Chesnutt himself did as a young man.

It is hard to avoid teleological readings of manuscripts. It is tempting to look for evidence of the final version in the earlier ones and to imagine an evolution based on gradual improvements. In the case, however, of a work that evolved over twelve years, it behooves us to consider what else might motivate revision. What were the shifting literary agendas for Chesnutt and for others around him during these years? What developments in political and social contexts might have shaped his thinking about the story he wanted to tell? He was just thirty and had only recently settled in Cleveland, away from his father and white grandfather, when he first drafted 'Rena'. By time he was putting finishing touches on the novel twelve years later, he had passed the Ohio bar and established a leading court stenography firm, and he was considering closing up shop to write full-time. In those same years, North Carolina, the setting for the novel and for most of Chesnutt's work, had seen the rise of the Fusion alliance between Populists and Republicans. Dedicated to political reform and progressive economic policies, this alliance led to more than 1000 blacks holding elected and appointed offices across the state. By the time Chesnutt was drafting the last version, the alliance had collapsed, and blacks had been expelled from almost all public offices.

Preliminary studies of the revisions to just a single character-Rena's mother, Molly - suggest the rich new veins for scholarship that a well-structured digital archive will facilitate. The extent of the revisions to Molly's character across the five versions suggests Chesnutt either cared a great deal about getting this character right or that he 
kept changing his mind about the best way to represent a salient feature of her life- $-\mathrm{a}$ long-term relationship with a white man. Sexual relationships across the color line were far more common, Chesnutt and others noted again and again, than was ever publicly acknowledged. The journalist Ida B. Wells argued repeatedly, in the same years Chesnutt was writing and revising 'Rena', that while the nation worried about black men preying on white women, the truth was that white men had long pursued relations with black women. Both of Chesnutt's parents were born of unsanctioned unions between a free black woman and a white landowner. In other words, in Molly's story Chesnutt was reckoning with the lives of both of his grandmothers and all the other black women who experienced colliding forces at the intersection of race, sexuality, economics, and power. Notably, the passages treating Molly are among the most revised in each version, with deletions and rewritings of entire sections. He adds in one version, 'she had not the slave's excuse'. But as he thinks through the complexities of familiar relationships forbidden by law and unsanctioned by religion, he adds that 'no other woman suffered'. He also, over the five versions, creates an ever more elaborate back story, and, in the final version, moves this back story from the opening to the middle of the narrative.

The Chesnutt manuscripts are fragile, and not many scholars have worked with them, as doing so requires travel to the main collection in Nashville and an appointment in an archive much loved and attended to but not richly resourced with staff to accommodate visitors. Nevertheless, interest in the pre-publication manuscript history of The House Behind the Cedars is rising. Recent studies tend to note that Chesnutt dedicated years to this work, often citing Chesnutt's letters about 'Rena Walden' to Walter Hines Page, George Washington Cable, and Richard W. Gilder. At a Chesnutt panel at the 2017 American Literature Association conference, the author of a chapter on The House Behind the Cedars for the recently released Approaches to Teaching the Works of Charles W. Chesnutt (Ashton and Bill 2017) lamented that she had not been able to work with the manuscripts because she knew that one or two visits to the archives would not be enough to read, transcribe, and track changes across pages, with almost every page heavily revised in Chesnutt's hand.

A digital archive will support precisely this kind of study and in a way the print volume of The House Behind the Cedars never can, even with extensive annotations, a robust editorial apparatus, and a full transcription of the first version. Thus, while a team of scholars will be working on the Oxford Complete Writings of Charles W. Chesnutt, another team will undertake the updating of the Chesnutt Digital Archive with the addition of a manuscript wing. Started twenty years ago as a project for an undergraduate class, the Chesnutt Digital Archive has grown and been maintained largely through the efforts of a single scholar. Indeed, this history, not uncommon for digital projects, underscores some of the well-known advantages of a print edition: a prestigious imprimatur, credentialing power for scholars, wide distribution, and established workflows, including peer review. But the digital archive, recently adopted by the Center for Digital Research in the Humanities (CDRH) at the University of Nebraska-Lincoln, now has a clear and distinct role to play in Chesnutt studies: creating access to the more than two thousand heavily revised typescripts, handwritten leaves, and galley pages held not only at Fisk University, but also the Cleveland Public Library and the Western Reserve Historical Society. The site will be converted from an HTML site into one based on the Text Encoding Initiative (TEI) P5/eXtensible mark-up 
language (XML). At the same time, we will tap the CDRH's strength in digital scholarly editing and demonstrated expertise in developing highly functional and well-designed TEI/XML sites based on both archival and published materials to develop the manuscript section of the site. CDRH will also ensure back-ups and long-term sustainability, having created such protocols for a wide range of projects they host, including the Walt Whitman Archive and the Willa Cather Archive.

As editors continue to define and weigh the distinct advantages of print and digital, it behooves us to see the interplay between the two as not only a matter of affordances intrinsic to the media themselves but also as historically and institutionally situated. In this case, Oxford's commitment to a print series played a role in Nebraska's decision to make an institutional commitment to a digital site. At the same time, the existence of the digital site played a role in Oxford's assessment of scholarly interest in Chesnutt—in looking for who might spearhead a print edition, Oxford turned to the editors of the digital site.

Digital archives are often constructed with an eye to expansion. The 'Rena' manuscripts represent only a quarter of the currently known extant Chesnutt manuscripts, and future plans include not only offering a complete manuscript archive but also a collection of letters to and from Chesnutt, as well as enhancements of the site's current collection of more than 300 contemporary reviews of Chesnutt's works as they came out in newspapers across the country. Digital projects also prosper when they attract new scholars to the ongoing endeavor. The 'Rena' manuscripts are especially tantalizing not only for the revelation that this iconic novel about passing began as a short story about black life, but also because they gesture to the wide range of inquiries that will be made possible by access to the Chesnutt's manuscripts. Scans will show how he wrote dialect, seemingly with great fluency in a flowing, quick hand between lines and along the margins of the typescript pages. They also show the care he took at times in finetuning spelling and syntax and altering whose speech is rendered in dialect. The 'Rena' manuscripts will also capture the attention of scholars interested in genre and form. While early studies praised Chesnutt as a realist and lamented his lapses into melodrama, more recent studies have suggested that his adroit formal maneuvers reveal a more complex poetics and politics than previously understood. They also offer a chance to witness Chesnutt's conversation with himself, over twelve years, that was, undoubtedly, about race and representation, but also about aesthetics, style, craft, voice, form, and literary traditions. Scholars are increasingly interested in Chesnutt's own reading, and several recent articles suggest that Chesnutt's works explicitly engage with other writers and other literary traditions. Chesnutt read widely, and photographs of his study show a desk with books piled high and shelves stuffed with books. A successful digital archive for Chesnutt will allow students and scholars to discover that a well-stocked bookcase in Molly's home, bequeathed by her white lover, though a small detail in the published novel, was carefully revised in every version, titles being added and eliminated.

\section{Final thoughts: hybrid editing and new directions in manuscript editing}

We believe that the Charles Chesnutt Digital Archive has plenty of room to develop in ways that do not compete with Oxford's publications plans or undercut Oxford's ability 
to sell the print volumes. A print edition enjoys authority stemming from the process of peer review and from what it earns via the quality of a text established through stated and adhered-to principles, annotations, introduction, and other apparatus. Moreover, as we know, print can be preserved for centuries. But definitive scholarly print editions can rarely do justice to the manuscript record. As indicated above, early development of the Chesnutt Digital Archive will focus on manuscripts. We will also add all texts in the public domain. The more the Chesnutt Digital Archive can become a useful resource with a wide array of content, the more we can fulfill our ambitions for it. A likely side effect of building a prominent and richly useful digital site will be to drive traffic to the print edition. Other areas that can be developed without competing with the Oxford University Press print edition include photographs, a bibliography of criticism, twoway correspondence, and full text of selected criticism that is either out of copyright or for which we have received permission to republish. How far and how quickly the Chesnutt Digital Archive is able to develop depends on many factors, including how successful the fundraising efforts are. There are of course many unknowns in a rapidly shifting environment. What new possibilities for editing will emerge as new technologies are developed? How will we engage our users? Can they directly contribute in some way and become user-contributors?

We may also use the Chesnutt Digital Archive, perhaps in an 'experiments and explorations' wing, to consider new approaches to rendering manuscripts in digital environments. The move in the 1970 s to create facsimile reproductions of manuscripts and publication projects such as the sixty-three-volume James Joyce Archive and R. W. Franklin's 1981 The Manuscript Books of Emily Dickinson led to a profound rethinking of texts, textual history, critical editions, and the roles of manuscripts. With the rapid expansion of access to digital images of manuscripts, we are, perhaps, at another pivotal moment in the history of textual editing. As Gabler (2002) has noted, we increasingly think of manuscripts as 'documentary sites of writing', and not merely as documents that transmit the text. The rise of genetic criticism has furthered this new understanding, and for many works it now seems appropriate to think of earlier versions not as precursors to the author's final intentions, realized in the published version, but rather as instances of different and equally interesting intentions. To the extent that there is a distinction between the presumed private nature of manuscript drafts and the public nature of published writings, manuscripts - especially when they deal with edgy, controversial, or explosive content - can sometimes be more revealing than a final product that has been filtered in the course of publication.

The Chesnutt Digital Archive will follow current standards for presenting manuscripts in a digital environment. Sharing a home at the University of Nebraska's CDRH with the Whitman Archive also means that the Chesnutt Digital Archive will benefit from and contribute to the ongoing elaboration of best practices for tagging manuscripts. The manuscript history for Leaves of Grass is densely complex, and the amount of scribal material in Whitman's hand is enormous. The experience and expertise gained through work on the Whitman will help inform experimentation to be undertaken with Chesnutt manuscripts.

We are in the very early stages of considering the possibility of supplementing the standard digital approach to rendering paper manuscripts with approaches borrowed from print and print aesthetics. This idea first arose in an undergraduate class on editing Chesnutt. Students took particular interest in print editions such as The Gorgeous 
Nothings: Emily Dickinson's Envelope Poems. They asked if it might be possible to render Chesnutt's manuscripts with similar elegance and fidelity to the original. The Gorgeous Nothings represents Dickinson poems on envelopes and other repurposed papers and scraps with both stunningly beautiful high-quality photographs and delicate, precise graphic diplomatic transcriptions that replicate the location of each handwritten word. Transcription into standard text is essential for searchability, and the use of a regularized font is important for readability. But the students asked if it might be possible to find a digital rendering that was as compelling as is sometimes accomplished in art-book print aesthetics. In the 'Rena' manuscripts, for example, Chesnutt's handwritten additions are squeezed between typed lines and flow up the margins. Shall we render these revisions into traditional lineation, with strikethroughs, carets, and superscript? Or might we also make graphic diplomatic transcriptions, capturing writing that goes off at angles and around the margins of the page? As Franklin (1998) admitted in his variorum edition of Dickinson, 'the manuscripts of this poet resist translation into the conventions of print' (p. ix). Howe (2013) notes, in her introduction to The Gorgeous Nothings, that although Franklin's earlier facsimile edition of The Manuscript Books of Emily Dickinson showed how the words 'spread across the entire space of a page,' there were no transcriptions (p. 6). So, the undergraduates asked, might one use the design and aesthetic capabilities that many digital designers achieve through Adobe and other proprietary software to capture the energy of Chesnutt's writing running up the side of the page and the physical constraints he confronted as he squeezed in a few more words on the very edge or on the verso side? Howe (2013) concludes her introduction by celebrating The Gorgeous Nothings: 'this edition itself is a work of art' (p. 7). What might it mean to think about our digital archives, and the editions of manuscripts created in digital environments, as works of art?

Open Access This article is distributed under the terms of the Creative Commons Attribution 4.0 International License (http://creativecommons.org/licenses/by/4.0/), which permits unrestricted use, distribution, and reproduction in any medium, provided you give appropriate credit to the original author(s) and the source, provide a link to the Creative Commons license, and indicate if changes were made.

\section{References}

Ashton, S., Bill H., ed. (2017). Approaches to Teaching the Works of Charles W. Chesnutt. Modern Language Association.

Chesnutt, C. W. (1900). The House Behind the Cedars. New York: Houghton Mifflin.

Chesnutt, C. W. (1993). The journals of Charles W. Chesnutt. In R. Brodhead (Ed.). Durham: Duke University Press.

Franklin, R. W. (1998). Introduction. In R. W. Franklin (Ed.), The poems of Emily Dickinson, variorum edition. Cambridge: Harvard University Press.

Gabler, H. W. (2002). The James Joyce Archive: A Publisher's Gift to Joyce Studies. Genetic Joyce Studies. Summer 2002. Retrieved from http://www.geneticjoycestudies.org/JJAGabler.htm. Accessed 15 March 2018.

Hackenberry, C. (1997). Introduction. In Charles W. Chesnutt, Mandy Oxendine (pp. i-xxvii). Urbana: University of Illinois Press.

Howe, S. (2013). Introduction. In M. Werner \& J. Bervin (Eds.), Emily Dickinson, The Gorgeous Nothings: Emily Dickinson's Envelope Poems. New York: New Directions. 
Mark Twain Project Online (2018). Retrieved from http:/www.marktwainproject.org/homepage.html. Accessed 15 March 2018.

Palmer, C. L. (2004). Thematic research collections. In S. Schreibman, R. Siemens, \& J. Unsworth (Eds.), A companion to digital humanities (pp. 348-365). Oxford: Blackwell Publishing.

Render S. L., ed. (1974). The Short Fiction of Charles W. Chesnutt. Howard University Press.

Shillingsburg, P. L. (2006). From Gutenberg to Google: Electronic representations of literary texts. Cambridge: Cambridge University Press.

The Walt Whitman Archive (2018). Retrieved from https://whitmanarchive.org/. Accessed 15 March 2018. 